\title{
The Utilization of the Portfolio to Build a Reading Culture on Trigonometry Courses
}

\author{
Agung Deddiliawan Ismail \\ Department of Mathematics Education \\ Universitas Muhammadiyah Malang, Indonesia \\ deddy@umm.ac.id
}

\begin{abstract}
The Purpose of the research that has been done is to provide portfolio task on each chapter in trigonometry courses then help students in familiarize themselves to read and give the learning experience. The portfolio will make students read and working on the question of the exercise. In addition to the student portfolio can evaluate the work that has been done as the answer to the task each chapter, middle examination and final examination. Research Methodology Research approach used in this research is a qualitative approach with a descriptive type. Based on the results of the research that has been carried out can be explained that at the beginning of the lecture students explained about creating a portfolio during one semester. The portfolio contains about a summary of every chapter courses that will be studied, tasks, the results of the test
\end{abstract}

Keywords—portfolio, reading culture, trigonometry

\section{INTRODUCTION}

PISA 2015 states the State of Indonesia is ranked 62 for science literacy, 63 for literacy mathematics, and literacy reading 64 . While the countries that join are as many as 70 countries. In general results in 2015 improved especially for the literacy of science and mathematical literacy. In PISA 2012 Indonesia's rank on science literacy and literacy mathematics is at position 64 and literacy reading at position 61 . Countries that joined at that time was 65 countries. UNESCO states that Indonesia's reading index is 0.001 . This means that from 1000 people only one who has interest in reading. This condition is also found by Siswati (2010) which states that students are more likely to like to observe rather than read. This causes the reading interest of students is very low. Survey data compiled by the Central Bureau of Statistics (CBS) in 2015 mentions the Indonesian people aged 10 years and over, there are $91.69 \%$ like to watch TV and $8.53 \%$ do not like. For reading interest only $17.66 \%$ and $82.34 \%$ do not like to read.

Reading activity is a positive activity that can help students to understand something. By reading will multiply one's insight and knowledge. Facts in the field mentioned that students tend to get bored reading the lecture book. Boredom that occurs because reading a lecture book is a form of coercion. Because the student was forced to be reluctant to read and understand the contents of the book. The quality of students in terms of literacy is still very low [3]. This low interest is influenced by several factors, both internal and external.
Based on the results of the interview with 51 students 2017 generation class $\mathrm{A}$ acquired data that there are only 3 from 51 students that fond of reading. Although the development of prehistoric times easier in download e-book as reading material. The results of the survey of students get the fact that from 51 students there are 4 students who read e-book but rarely read it. See this condition lecturers have an obligation to help and motivate students in building the reading habit. Based on Ristek dikti Ministry Regulation No. 2 Year 2016 explained that the lecturers are professional educators and scientists with the main task of transformation, inclined and disseminate knowledge and technology through education, research and dedication to the community. To familiarize the students read it needs to be a method that can make students read consistent and structured. The portfolio can be used as a tool to help students. Portfolio can be charged with the result of the activities of summarizes and worked done consistently can be used as the method as part of the effort to make the students to get accustomed to read. Based on the problem and the purpose of this research is to build a reading culture students with portfolios.

Reading is a process to know a word and integrate the meaning of the word in a sentence and the structure of the reading material. So that the end result of the process of reading is the one able to create the core of the reading material. Reading is a way or means of medium in a learning throughout the life of the life-long learning). This is similar to that expressed [1] who said that reading is a process which developed (a development process).

The reading culture or reading habit is a mandatory practical (practical necessity) in the modern world [8]. Read as a personal activity in general has become a need in society in the developed countries, but this is not the case in the community in developing countries such as Indonesia.

According to the Great Dictionary Bahasa Indonesia reading is to see and understand the content of what is written with the list or only in the heart. Reading is a complex activity by releasing a large number of actions that separate settlements, include: people must use the understanding and imagination, observe, and remember [10]. According to Gie quoted [2] Read is a series of activities of the mind of the person who carried out with a sense of attention to understand a description that is seen by the sense of vision in the form of a letter or other signs. 
The kinds of purpose read [6]:

1. Pleasure.

2. Enhance reading loud voice.

3. Using a specific strategy.

4. Renew their knowledge about a topic.

5. Associate the new information with the information that has been omitted.

6. Obtain information for oral reports or written.

7. Confirm or reject prediction.

8. Displays an experiment or applying the information obtained from a text in other ways and learn about the structure of the text.

9. The answer to the question of specific questions.

The Benefits of Reading many benefits that can be obtained when done by someone with a really good for themselves and the community. [4] explains the benefits of read as follows:

1. The Benefits of reading for individuals among others:

a. Can be a way to explore a problem with learn something until the issue can add to the knowledge that is associated with increased skill.

b. Can increase general knowledge about something question.

c. To search for the values of life as the interests of education themselves.

d. To fill in the spare time by observing the art of literature or the story fiction story of quality.

2. The benefits for the development of the community among others:

a. Improve general knowledge society.

b. Increase the intelligence of the community and so they have a greater ability to develop themselves.

c. The media can be used as a light and guidance to the development of society.

d. Grow critical attitude that is able to make corrections about the existence of the things that harm society.

e. As media delivery of new ideas that are useful to improve the development of the community.

Based on [11], summarize the characteristics of the portfolio as follows: (a) Opportunities for learners to conduct self-evaluation, (b) Processes for learning activities and evaluation programs, (c) Methods to monitor (d) A learner's accountability of his learning activities, (f) A record of the learners' creative process, his historical knowledge, his critical thinking, his aesthetic growth and the results of his learning, $(\mathrm{g})$ teaching and learning tools that facilitate dialogue between learners and teachers, (h) Evidence of real development that shows the relationship between the creative process of the learners, their work and reflections over a period of time, (i) ) A development that includes cultural literacy and gender understanding (how to respond to change or difference), and (j) Containers that hold facts / work (art ) and a written reflection on a meaning built between Master and the learner.

\section{RESEARCH METHOD}

The research approach used in this research is a qualitative approach. With the types of descriptive research. Research object is a student of the host class 2017 A. The technique of data collection using the technique of observation. Data analysis technique that used is qualitative data analysis techniques using based on [5] which consists of the collection of data, data reduction and logical deduction data.designations.

\section{RESULT AND DISCUSSION}

Based on the results of data analysis can be explained that to build a reading culture in lecturer students designing lecturing trigonometry using portfolio-based learning methods. At the initial meeting the lecturer gave an introduction to trigonometry history by using question and answer method. Based on the observations indicate that no student can give his opinion on trigonometric history. Lecturers describe the interest of Indonesian students reading. Furthermore, the lecturer also asked the interest of reading class A student of class of 2017 who went through. Based on the low interest in reading the students then the lecturers provide solutions that is by using the portfolio in Trigonometry learning.

The second meeting of the students was asked to make a summary of "Radian and Degree Measure". At the second meeting the students were invited to discuss the concept of angle size in the form of Radian and Degree. In learning the students are asked to use the concatenation to build the concept. Students are invited to discuss the history of Trigonometry. Based on the results of observations students have started to argue by using his summary to answer. There are 7 students who gave their opinion. Furthermore, students are directed to develop the concept of angle size using Trigonometry history. At the end of the learning the students were given the task of doing the exercises and making a summary of "Trigonometric Functions: The Circle Unit".

The third meeting, students are asked to draw a Circle Unit. Furthermore, students are invited to discuss about what is the relationship of Circle Unit with Trigonometric Functions. Based on the results of observation shows that although it has made a summary, students still have difficulty in associating Unit Circle with Trigonometric Functions. Furthermore, students are invited to make a line within the Circle Unit. The lines formed are then summarized. At the end of the course students are asked to make a summary of "Right Triangle Trigonometry" and apply various forms of Right Triangle.

Fourth meeting, at the beginning of the lecture students are asked to find the Right Triangle built around the class. After identifying the Right Triangle wake up, students are asked to look for the lengths of each side. Furthermore, students are invited to discuss the concept of Trigonometric Functions based on Right Triangle. Furthermore, students are required to measure the angle of the Right Triangle wake up. At the end of the course students are asked to summarize the material 
"Graphs of Sine and Cosine Functions" and ask students to do the exercises.

The fifth meeting, students are invited to discuss about the shape of the curve sine and cosine in the form of wavy lines. Based on the results of the discussion seen that students think based on the summary. The result of the observation showed that the students explained that the graph of wave formed by waves is dominated by domain, function and codomain. Students are also invited to discuss the differences in sine, cosine and tangent graphics. When asked to draw various functions such as $y=3 \sin 3 x$ and $y=2 \cos 3 x$ with interval $-2 \pi \leq x \leq 2 \pi$ and based on observation students easily draw it. At the end of the lesson the students are asked to do the exercises for drawing other Trigonometry functions and making a summary of "Using Fundamental Identities"

The sixth meeting, at the beginning of the lecturers' study, asked the students to explain what is meant by "Using Fundamental Identities". Some students argue by using their summaries and answer that "Using Fundamental Identities" is used to evaluate, simplify, develop and resolve trigonometric equations. They explain that there are 5 types of identities: Reciprocal Identities, Quotient Identities, Pythagorean Identities, Cofunction Identities, Even / Odd Identities. Finally, the students are asked to do simple questions using Fundamental Identities.

\section{CONCLUSION}

Based on the results of research can be concluded that by using the portfolio can familiarize students to read. Summarizing and working on problems is an activity that indirectly requires students to read consistently.

\section{REFERENCES}

[1] Allen, Edward David, and Rebecca M. Valette. Modern Language Classroom Techniques : A Handbook. New York : Hdrcourt Brace Jovanovich, Inc., 1972.Badan Pusat Statistik. Indikator Sosial Budaya tahun 2003,2006, 2009, 2012, 2015 . 5 Oktober 2017. https://www.bps.go.id/

[2] Damaiwati, Elly. Karena Buku Senikmat Susu. Solo : Indiva Media Kreasi. 2007

[3] Gustini at all.. Budaya Literasi. Yogyakarta: Deepublish. 2016

[4] Kamah at al. Pedoman Pembinaan Minat Baca. Jakarta: Perpustakaan Nasional RI. 2002

[5] Miles,M.B, Huberman,A.M, dan Saldana,J. 2014.Qualitative Data Analysis, A Methods Sourcebook Edition 3. USA : Sage Publications.

[6] Rahim, Farida. Pengajaran Membaca di Sekolah Dasar. Jakarta : Bumi Aksara. 2008.

[7] Ristekdikti Ministry Regulation Republik Indonesia No 2 Tahun 2016 Tentang Perubahan Atas Peraturan Menteri Riset, Teknologi, dan Pendidikan Tinggi Nomor 26 Tahun 2015 Tentang Registrasi Pendidik pada Perguruan Tinggi

[8] Siregar, A. Ridwan. Perpustakaan : Energi Pembangunan Bangsa. Medan : USU Press. 2004

[9] Siswati. Minat Membaca pada mahasiswa (Studi Deskriptif pada Mahasiswa Fakultas Psikologi UNDIP). Seminar ASEAN Psycology and Humanity. 2016.

[10] Soedarso. Speed Reading. Jakarta: Gramedia Pustaka Utama. 2004.

[11] Swann, Annette C.; Bickley-Green, Cynthia. 1993. Basic Uses of Portfolio in Art Education Assessment.NAEA Advisory. Reston. 